\title{
ASSET PRICES AND CURRENT ACCOUNT FLUCTUATIONS IN G7 ECONOMIES
}




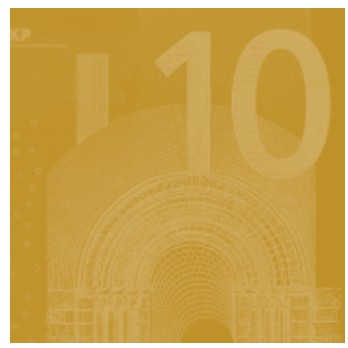

\section{WORKING PAPER SERIES}

NO IOI4 / FEBRUARY 2009

\section{ASSET PRICES AND CURRENT ACCOUNT FLUCTUATIONS IN G7 ECONOMIES 1}

by Marcel Fratzscher and Roland Straub ${ }^{2}$
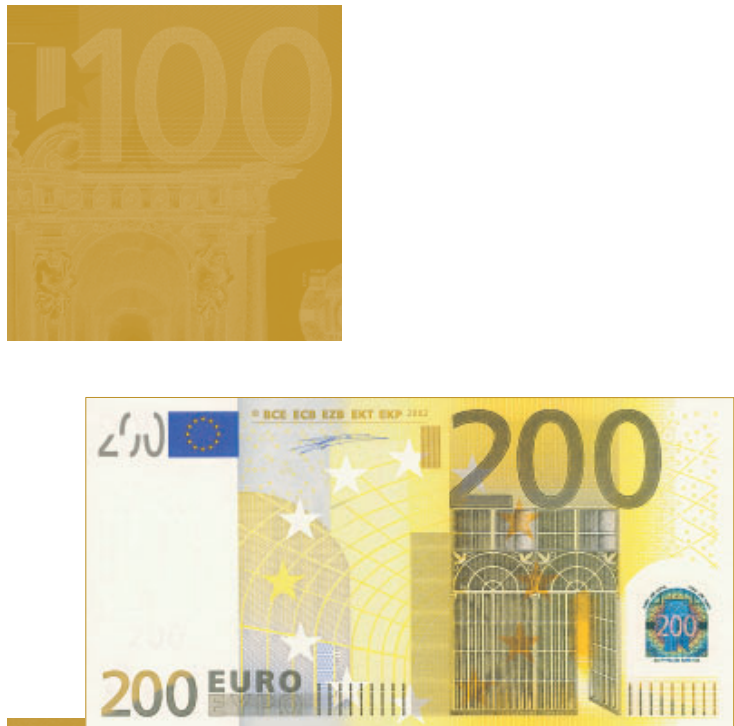

In 2009 all ECB

This paper can be downloaded without charge from http://www.ecb.europa.eu or from the Social Science Research Network electronic library at http://ssrn.com/abstract_id $=1333574$.

I This paper is forthcoming in IMF Staff Papers. We would like to thank the participants at the conference on "Current Account Sustainability in Major Advanced Economies" at the University of Wisconsin, Madison, and in particular our discussant, Ken West, as well as Akito Matsumoto and an anonymous referee for comments and discussion. The views expressed in this paper are those of the authors and do not necessarily reflect those of the European Central Bank 2 European Central Bank, Kaiserstrasse 29, D-603II Frankfurt am Main, Germany; email: Marcel. 
(C) European Central Bank, 2009

Address

Kaiserstrasse 29

60311 Frankfurt am Main, Germany

Postal address

Postfach 160319

60066 Frankfurt am Main, Germany

Telephone

+496913440

Website

http://www.ecb.europa.eu

\section{Fax}

+496913446000

All rights reserved.

Any reproduction publication and reprint in the form of a different publication, whether printed or produced electronically, in whole or in part, is permitted only with the explicit written authorisation of the ECB or the author(s).

The views expressed in this paper do not necessarily reflect those of the European Central Bank

The statement of purpose for the ECB Working Paper Series is available from the ECB website, http://www.ecb.europa. eu/pub/scientific/wps/date/html/index. en.html

ISSN 1725-2806 (online) 


\section{CONTENTS}

Abstract

Non-technical summary

1 Introduction

2 Methodology

2.1 Deriving the sign restrictions

2.2 Model specification and data

2.3 Implementaion of the sign restrictions

3 Empirical results

3.1 Benchmark results

3.2 Robustness and extensions

4 Conclusions

References

Data appendix

European Central Bank Working Paper Series 


\begin{abstract}
The paper analyses the effect of equity price shocks on current account positions for the G7 industrialized countries in 1974-2007. It uses a Bayesian VAR with sign restrictions for the identification of asset price shocks and to test empirically for their effect on current accounts. Such shocks are found to exert a sizeable effect, with a 10 percent equity price increase for instance in the United States relative to the rest of the world worsening the US trade balance by 0.9 percentage points after 16 quarters. However, the response of the trade balance to equity price shocks varies substantially across countries. The evidence suggests that the channels accounting for this heterogeneity function both through wealth effects on private consumption and to some extent through the real exchange rate of countries.
\end{abstract}

JEL Classification: E2; F32; F40; G1.

Keywords: asset prices; current account; identification; Bayesian VAR; financial markets; industrialized economies. 


\section{Non-technical summary}

Current account positions have hardly ever been so dispersed globally as they are today. It is not only that the largest economy, the United States, has been recording large current account deficits for more than a decade, but other industrialized countries, such as the UK and Australia, and some emerging and transition economies have even larger deficits. By contrast, countries such as China, Japan and oil exporters register corresponding large trade surpluses. At the same time, asset prices have gone through a marked cycle over the past decade, with equity markets rising substantially in the second half of the 1990s and in 2002-06 and declining in 2001-02. The financial market crisis of 2007-08 has made the importance of asset prices for the global economy more than apparent. Despite the financial crisis, the role of asset prices for the global economy will most likely increase further as financial markets deepen and emerging economies liberalize and integrate.

The paper analyses the impact of asset price shocks on the current account. The objective is not only to grasp the magnitude of the effect of asset prices on trade, but also to understand the channels through which this effect materializes. Asset price shocks affect net exports through a wealth channel as households adjust saving and consumption decisions, and through an exchange rate and terms of trade channel, altering the relative prices of domestic and foreign goods. Equally importantly, asset prices may exert different effects across economies, as those with deeper yet more closed financial markets may respond more strongly.

The focus of the paper is on the G7 industrialized economies and on the role of asset price shocks during the period 1974-2007. We use the sign restrictions derived in Fratzscher and Straub (2008), who build an open-economy DSGE model, in which changes to asset prices influence private consumption through wealth effects. We then employ a Bayesian VAR, following Canova and De Nicoló (2002), Uhlig (2005) and Peersman (2003), using sign restrictions to test for the effect of asset price shocks in the data. This methodology not only requires imposing a relatively small and intuitive number of identification restrictions, but importantly it also allows us to distinguish asset price shocks from other types of shocks, such as to technology, monetary policy and government spending.

Our empirical findings show that asset prices exert a sizeable effect on the trade balance of countries. The channels through which asset prices influence net exports are both through wealth effects on private consumption and to some extent through the exchange rate. An increase in asset prices tends to have a positive impact on short-term interest rates and inflation, and leads to an appreciation of the real effective exchange rate and a sizeable increase in consumption. Moreover, we find a large degree of cross-country heterogeneity in the impulse response pattern. The US trade balance is among the most sensitive as net exports, on average, decline by 0.91 percentage points after 16 quarters in response to a 10 percent increase in US equity prices relative to the rest of the world. The trade balances of most other countries react substantially less. 


\section{Introduction}

Current account positions have hardly ever been so dispersed globally as they are today. It is not only that the largest economy, the United States, has been recording a current account deficit in excess of 5 percent for several years, but other industrialized countries, such as the UK and Australia, and some emerging markets and transition economies have similar or even larger deficits. By contrast, countries such as China, Japan and oil exporters register corresponding large trade surpluses. At the same time, asset prices have gone through a marked cycle over the past decade, with equity markets rising substantially in the second half of the 1990s and in 200206 and declining in 2001-02. The financial market crisis of 2007-08 has made the importance of asset prices for the global economy more than apparent. Despite the financial crisis, the role of asset prices for the global economy will most likely increase further as financial markets deepen and emerging economies liberalize and integrate.

The paper analyses the impact of asset price shocks on the current account. The objective is not only to grasp the magnitude of the effect of asset prices on trade, but also to understand the channels through which this effect materializes. Asset price shocks affect net exports through a wealth channel as households adjust saving and consumption decisions, and through an exchange rate and terms of trade channel, altering the relative prices of domestic and foreign goods. Equally importantly, asset prices may exert different effects across economies, as those with deeper yet more closed financial markets may respond more strongly.

The focus of the paper is on the G7 industrialized economies and on the role of asset price shocks during the period 1974-2007. We use the sign restrictions derived in Fratzscher and Straub (2008), who build an open-economy DSGE model, in which changes to asset prices influence private consumption through wealth effects. The effect of stock market wealth on consumption arises from the finite lifetime horizon of households in the model. We then employ a Bayesian VAR, following Canova and De Nicoló (2002), Uhlig (2005) and Peersman (2003), using sign restrictions to test for the effect of asset price shocks in the data. This methodology not only requires imposing a relatively small and intuitive number of identification restrictions, but importantly it also allows us to distinguish asset price shocks from other types of shocks, such as to technology, monetary policy and government spending. Our empirical implementation follows closely that of Fratzscher and Straub (2008), as well as that of Fratzscher, Juvenal and Sarno (2007), who test for the effect of equity market shocks, housing price shocks and exchange rate shocks on the trade balance of the United States. The latter paper shows that equity market shocks and housing price shocks have been important drivers explaining more than 30 percent of the variation of the US trade balance, whereas exchange rates account for a much smaller share.

Our empirical findings show that asset prices exert a sizeable effect on the trade 
balance of countries. The channels through which asset prices influence net exports are both through wealth effects on private consumption and to some extent through the exchange rate. An increase in asset prices tends to have a positive impact on short-term interest rates and inflation, and leads to an appreciation of the real effective exchange rate and a sizeable increase in consumption. Moreover, we find a large degree of cross-country heterogeneity in the impulse response pattern. The US trade balance is among the most sensitive as net exports, on average, decline by 0.91 percentage points after 16 quarters in response to a 10 percent increase in US equity prices relative to the rest of the world. The trade balances of most other countries react substantially less.

The paper is related to three fields of the literature. A first strand focuses on the drivers of the large and persistent global current account imbalances. Several papers emphasize the importance of a "saving glut" (Bernanke 2005) in many emerging markets and commodity-exporting countries, partly stemming from the underdevelopment and lack of integration of financial markets in those economies (Caballero et al. 2006, Ju and Wei 2006), as well as the increasing role of ensuing valuation effects on gross international asset positions (Gourinchas and Rey 2007, Lane and Milesi-Ferretti, 2005) and a pre-cautionary motive as a rationale for high saving rates (e.g. Gruber and Kamin 2007, Chinn and Ito, 2007). Other studies to explain the dispersion in current account positions stress the role of productivity differentials (e.g. Corsetti et al. 2006, Bussiere et al., 2005), or link it to the "great moderation" which has induced a decline in income volatility and uncertainty (Fogli and Perri, 2006).

As to the second area, a vast literature identifies and measures the effect of price changes in various financial assets on private consumption (e.g. Betraut 2002, Case et al. 2005). Most of this literature find a significant effect of both equity wealth and housing wealth on private consumption. However, there is still substantial controversy as to the magnitude and precise functioning of this channel as for instance exemplified by the conflicting results found by Palumbo, Rudd, and Whelan (2006) and Lettau and Ludvigson (2004). The effect of such a wealth channel on the external dimension of countries, in particular the current account and the exchange rate, has so far received little attention in the literature. From a current policy perspective, is has been argued by some that the US dollar decline would have to be very large as suggested by several studies (Blanchard et al. 2005, Obstfeld and Rogoff 2005, Krugman 2007).

The third area relates to the crucial issue of the structural interpretation of asset price shocks. Although we can separate an asset price shock from the standard macroeconomic shocks usually analyzed (technology, monetary policy and fiscal policy), it is not clear what asset price changes represent structurally. One interpretation of an asset price shock is that of a "news" shock, along the line of work by Beaudry and Portier (2006, 2007), in which asset prices adjust because of altered expectations about the likelihood of future outcomes, such as to economic funda- 
mentals. Such changes in expectations should then, in turn, be reflected in today's asset prices as these represent the net discounted value of all future fundamentals. This is also related to the work by Engel and Rogers (2006), who show that the large size of the US current account deficit is consistent with expectations of an increasing share of US output in the world. Moreover, the asset price shock we identify here can be thought of being related to the shock to monetary policy expectations analysed in Matsumoto et al. (2008), who show how shocks to expectations to monetary policy and to technology may alter the size and even the sign of the correlation between equity returns and exchange rate returns.

An alternative interpretation is that asset price shocks reflect rational bubbles, as in Kraay and Ventura (2005) and Ventura (2001). They argue that the sharp increase in asset prices over the past decade may largely reflect a bubble, which is rational because of market expectations that this increase may be persistent. Both interpretations are observationally equivalent to what we understand and see in the behavior of economic fundamentals. We are agnostic about these interpretations; the crucial point is that asset price shocks reflect factors that function primarily through asset prices. The purpose and intended contribution of this paper is to improve our understanding of how this asset price channel functions.

The paper is organized as follows. Section 2 derives sign restrictions for the empirical identification of asset price shocks, and that section also outlines the model specification, the data and the empirical implementation of the sign restrictions. The benchmark results and various robustness tests are presented in section 3. A discussion of the results and conclusions follow in section 4 .

\section{Methodology}

\subsection{Deriving the sign restrictions}

In this section we discuss the set of sign restrictions to identify asset price shocks. In particular, we utilize restrictions, discussed in detail in Fratzscher and Straub (2008) - which is based on the empirical strategy discussed in Peersman and Straub (2006) - who identify asset-price shocks uniquely and distinguish them from a set of other shocks that are discussed as determinants of current account fluctuations in the literature. Table 1 summarizes the sign restrictions used for the identification in our structural VAR. We associate positive asset price shocks (i.e. an exogenous increase in asset prices) with a rise in consumption, inflation, and interest rates. As discussed in a finite lifetime DSGE model in Fratzscher and Straub (2008), the rise in current stock market wealth triggers an increase in private consumption. The latter induces a surge in inflation rates, and under the assumption of an active monetary policy rule, an increase in interest rates.

As discussed above, the structural interpretation of such an asset price shock may be understood as being a "news" shock, in which asset prices adjust because of 
altered expectations about the likelihood of future outcomes, such as to economic fundamentals. In Beaudry and Portier (2006 and 2007), such a news shock can be changes to expectations about future technology, thus inducing an adjustment today. For instance, such a positive news shock due to an increase in expected future productivity should lead to a rise in equity returns, as asset prices represent the net discounted value of all future fundamentals. In turn, both inflation and private consumption tend to rise as supply declines as labour supply is reduced in anticipation of such a positive future shock.

Note that this reaction of the different macroeconomic variables is fundamentally different from the response following technology, government spending and monetary policy shocks. First, technology shocks that trigger a rise in consumption are usually associated with a fall in inflation rates. Second, monetary policy shocks that induce a positive response of consumption and inflation are characterized by a fall in interest rates. Third, in the model a fall in government spending, financed e.g. by lump-sum taxes for simplicity, is associated by a rise in private consumption and inflation, but a fall in aggregate output. As a result, the reaction of policy interest rates depends obviously on the monetary policy rule. As argued in Fratzscher and Straub (2008), a standard Taylor rule implies a fall in interest rates, as the rise in inflation is relatively small, while the response of output is more pronounced for a wide range of structural parameters. Note that, although we base our sign restriction identification strategy on the predictions of a theoretical model, we do not have to restrict the response of the current account and the real exchange rate, the main variables of interest. In this respect, we can let the data to speak for itself.

Table 1: Theoretical Impulse Response Functions

\begin{tabular}{lcccc}
\hline & consumption & inflation & interest rate & asset prices \\
\hline Technology shock & $\uparrow$ & $\downarrow$ & & \\
Asset-price shock & $\uparrow$ & $\uparrow$ & $\uparrow$ & $\uparrow$ \\
Government spending shock & $\uparrow$ & $\uparrow$ & $\downarrow$ & \\
Monetary policy shock & $\uparrow$ & $\uparrow$ & $\downarrow$ & \\
\hline
\end{tabular}

A crucial issue is the structural interpretation of asset price shocks. The identifying restrictions above separate an asset price shock from the standard macroeconomic shocks usually analyzed (technology, monetary policy and government spending), without identifying the structural factors behind the asset price increase. Note that other "demand side shocks" such as shocks to time preferences or distortionary taxes might imply, under certain assumptions, similar patterns for the endogenous variables as asset price shocks. On the other hand, exogenous changes in distortionary taxes or time-preference rates are unlikely to be an important determinant of business cycles at a quarterly level.

What is our interpretation of asset price shocks? As discussed above, one interpretation of an asset price shock is that of a "news" shock (Beaudry and Portier 
2006, 2007), in which asset prices adjust because of changed expectations about the likelihood of future outcomes, such as to economic fundamentals; or as in Engel and Rogers (2006), where current account changes are consistent with changing expectations of relative output shares. Note that in a finite life-time model, as discussed above, domestic consumption will adjust following a news shock about e.g. a change in future productivity mainly through the wealth effects induced by fluctuations in asset prices, as asset prices correspond to the expected net discounted value of future profits. An alternative interpretation is that asset price shocks reflect rational bubbles, as in Kraay and Ventura (2005) and Ventura (2001). We are agnostic about these interpretations; the main point is that asset price shocks reflect factors that function primarily through asset prices. The objective of the empirical exercise is to illustrate how this asset price channel functions.

\subsection{Model specification and data}

Consider the following specification for a vector of endogenous variables $Y_{t}$ :

$$
Y_{t}=a+\sum_{i=1}^{n} A_{i} Y_{t-i}+B \varepsilon_{t}
$$

where $a$ is a vector of constants, $A_{i}$ is an $(n \times n)$ matrix of autoregressive coefficients and $\varepsilon_{t}$ is a vector of structural disturbances. Identification of (1) requires imposing $\mathrm{n}(\mathrm{n}-1) / 2$ restrictions on $\mathrm{B}$, which we achieve by using the sign restrictions shown in Table 1. Our sign restriction approach is based on Canova and De Nicoló (2002), Uhlig (2005) and Peersman (2003), discussed in some detail in the next section.

Our VAR includes six variables: $Y_{t}=\left[\begin{array}{llllll}E Q & c & i & \pi & T B & R E E R\end{array}\right]$, a relatively standard specification as, for instance, also used in Fratzscher, Juvenal and Sarno (2007), i.e. private consumption (c), short-term interest rates $(i)$, inflation $(\pi)$, equity returns $(E Q)$, as well as the trade balance $(T B)$ and the real effective exchange rate $(R E E R)$.

Our country sample focuses on the G7 industrialized countries. The time period for the empirical analysis is 1974 to 2007, using quarterly data. We use 1974 as the starting point of the analysis as it is the start of the floating exchange rate period after the collapse of the Bretton Woods system. Of course, it would desirable to extend the country sample, in particular to emerging market economies (EMEs) as these are becoming increasingly important for the global economy and for global financial markets. In the robustness analysis, we extend our country sample by including an additional 28 EMEs and other industrialized countries in the "rest of the world". However, data availability limits the time period to 1990-2007 or 1995-2007. Table 3 in the appendix lists the countries included.

For our empirical estimation we use relative variables, i.e. we specify each variable in domestic versus rest-of-the-world terms. More precisely, consumption $c$ is the difference in log private consumption in the domestic economy and log private 
consumption in the rest of the world, both expressed in US dollar (using end-ofperiod exchange rates). Interest rates $i$ are the percentage difference of domestic short-term (money market) rates from those in the rest of the world, while inflation $\pi$ is the corresponding percentage difference in CPI inflation. The rest of the world for all three variables comprises the other 15 economies (in the benchmark sample) or other 43 countries (in the extended sample), with each country being weighted by its GDP share in the sample group.

We use relative variables for two reasons. First, for consistency reasons, as both the trade balance and the exchange rate of a country are intrinsically "relative", i.e. both of these variables express a relative flow or a relative price. Hence expressing consumption, inflation and interest rates as relative variables is consistent with this empirical specification. The second reason for using relative variables is identification. As asset price movements tend to be highly positively correlated globally, an increase in equity prices in the home country may reflect an even stronger rise in equity values abroad. In this case and under certain conditions, we would expect the domestic trade balance to improve due to the wealth effects rather than deteriorate. Of course, one may include domestic and foreign asset returns, consumption, inflation and interest rates separately in the VAR specification; however, we did not chose such a specification for computational reasons. ${ }^{1}$

Our preferred measure of asset prices $E Q$ is the difference between domestic equity returns and foreign equity returns, both measured in local currency terms. We use local currencies to express returns, rather than US dollars, because we want to obtain a measure of asset price shocks that excludes exchange rate movements. ${ }^{2}$ Moreover, we use shocks to equity prices, rather than changes to market capitalization, as our preferred measures because our primary interest is in the cross-country heterogeneity in the responses of the trade balance and the exchange rate. The rest-of-the-world group comprises the other countries in the sample, with each of these countries being weighted by their equity market capitalization. We use equity market capitalization weights, rather than GDP weights, because asset shocks are likely to affect the trade balance of countries partly through wealth effects, which in turn should be related to the size of financial wealth held by households, which is better proxied by market capitalization than GDP. In the section on the robustness analysis below we will discuss how alternative specifications of asset price shocks influence the empirical findings.

The trade balance $T B$ is measured as a ratio to domestic GDP. We use the trade balance, rather than the current account, as we are interested in the effect of asset price shocks on net exports and want to exclude the effect on income. We use the total trade balance, rather than the trade balance only vis-a-vis the countries in the

\footnotetext{
${ }^{1}$ There is an emerging VAR literature using various aggregation methods for the rest of the world - see the GVAR literature based on the work of Pesaran, Schuermann and Weiner (2004).

${ }^{2} \mathrm{Hau}$ and Rey (2006) and Andersen et al. (2007), for instance, show that there tends to be a negative correlation between equity returns and exchange rate returns in the data for several industrialized countries.
} 
sample, though the results change little when using the extended country sample including EMEs; a point to which we return in the robustness analysis. As the final variable, the real effective exchange rate $R E E R$ uses trade weights for a broad set of partner countries, and is expressed in logs.

As to the data sources, the trade balance, consumption, inflation and short-term interest rates come from the IMF's International Financial Statistics (IFS). Equity returns and equity market capitalization are MSCI market indices and are sourced from Bloomberg while we took the real effective exchange rates from the IFS and the OECD. Table 4 in the appendix lists the variables, their definitions and sources.

\subsection{Implementation of the sign restrictions}

Before moving on to the empirical results, it is useful to explain how we implement the sign restrictions in our VAR. For a detailed explanation, we refer to Peersman (2003). Consider equation (1). Since the shocks are mutually orthogonal, $E\left(\varepsilon_{t} \varepsilon_{t}^{\prime}\right)=$ $I$, the variance-covariance matrix of equation (1) is equal to: $\Omega=B B^{\prime}$. For any possible orthogonal decomposition $B$, we can find an infinite number of admissible decompositions of $\Omega, \Omega=B Q Q^{\prime} B^{\prime}$, where $Q$ is any orthonormal matrix, i.e. $Q Q^{\prime}=$ $I$. Possible candidates for $B$ are the Choleski factor of $\Omega$ or the eigenvalue-eigenvector decomposition, $\Omega=P D P^{\prime}=B B^{\prime}$, where $P$ is a matrix of eigenvectors, $D$ is a diagonal matrix with eigenvalues on the main diagonal and $B=P D^{\frac{1}{2}}$. Following Canova and De Nicoló (2002) and Peersman (2003), we start from the latter in our analysis. More specifically, $P=\prod_{m, n} Q_{m, n}(\theta)$ with $Q_{m, n}(\theta)$ being rotation matrices of the form:

$$
Q_{m, n}(\theta)=\left[\begin{array}{ccccccc}
1 & \cdots & 0 & \cdots & 0 & \cdots & 0 \\
\cdots & \ddots & \cdots & \cdots & \cdots & \cdots & \cdots \\
0 & \cdots & \cos (\theta) & \cdots & -\sin (\theta) & \cdots & 0 \\
\vdots & \vdots & \vdots & 1 & \vdots & \vdots & \vdots \\
0 & \cdots & \sin (\theta) & \cdots & \cos (\theta) & \cdots & 0 \\
\cdots & \cdots & \cdots & \cdots & \cdots & \ddots & \cdots \\
0 & \cdots & 0 & \cdots & 0 & \cdots & 1
\end{array}\right]
$$

Since we have six variables in our model, there are $n(n-1) / 2=15$ bivariate rotations of different elements of the VAR: $\theta=\theta_{1}, \cdots, \theta_{15}$, and rows $m$ and $n$ are rotated by the angle $\theta_{i}$ in equation (2). All possible rotations can be produced by varying the 15 parameters $\theta_{i}$ in the range $[0, \pi]$. For the contemporaneous impact matrix determined by each point in the grid, $B_{j}$, we generate the corresponding impulse responses:

$$
R_{j, t+k}=A(L)^{-1} B_{j} \varepsilon_{t}
$$

A sign restriction on the impulse response of variable $p$ at lag $k$ to a shock in $q$ at time $t$ is of the form:

$$
R_{j, t+k}^{p q} \gtrless 0
$$


We impose the sign restrictions for $k=4$ lags; choosing a different length, however, does not alter the findings in a meaningful way. Following Uhlig (2005) and Peersman (2003), we use a Bayesian approach for estimation and inference. Our prior and posterior belong to the Normal-Wishart family for drawing error bands. Because there are an infinite number of admissible decompositions for each draw from the posterior when using sign restrictions, we use the following procedure. To draw the "candidate truths" from the posterior, we take a joint draw from the posterior for the usual unrestricted Normal-Wishart posterior for the VAR parameters as well as a uniform distribution for the rotation matrices, using 1000 draws. We then construct impulse response functions. If all the imposed conditions of the impulse responses are satisfied, we keep the draw, while other decompositions are rejected. This means that these draws receive zero prior weight. Based on the draws kept, we calculate statistics and report the median responses, together with 84th and 16th percentile error bands.

\section{Empirical results}

This section presents the empirical results from the structural VAR with sign restrictions, applied to the G7 economies in the period 1974-2007. We also present various extensions to check for the sensitivity and robustness of the findings.

\subsection{Benchmark results}

Figures 1-7 shows the impulse responses of the six variables, for each of the countries in our country sample of G7 countries, to a 10 percent positive asset market shock based on our Bayesian VAR model. The shaded areas indicate the 16 and 84 percentiles of the posterior distribution, following the convention in the literature. Table 2 summarizes the point estimates of the impulse responses at various time horizons.

As to the United States (Figure 1), a 10 percent increase in (relative) US equity prices leads to a substantial worsening in the US trade balance. The effect of the asset price shock increases gradually over time up to 16-20 quarters, when it reduces the US trade balances by 0.91 percentage points (p.p.) of US GDP. This effect of asset prices on the trade balance appears to stem from two channels, a first one through wealth effects and a second related to the exchange rate. The importance of wealth effects is evident by the strong and quite persistent increase in private consumption, which in turn leads to a higher demand for imports.

The role of the exchange rate channel is underlined by the significant appreciation of the REER after a positive asset price shock. The real appreciation is likely to be influenced both by the increase in domestic inflation and in domestic interest rates, though both of these responses are more short-lived as inflation and nominal interest rates revert back within 10 quarters. The rise in interest rates and real 
appreciation of the exchange rate is consistent with the evidence of the presence of a significant forward discount bias found in the literature (e.g. Engel, 1996), as well as the more recent evidence stressing the importance of monetary policy or 'Taylor-rule' fundamentals for exchange rate determination (Engel and West, 2005, Mark, 2005, Clarida and Waldman, 2007). ${ }^{3}$

Figures 2-7 shows the corresponding impulse responses for the other G7 countries of the sample. With a few exceptions, the patterns of the impulse responses are quite similar across countries: the trade balance of most countries deteriorates in response to a positive asset price shock, though the permanence of this response is mostly somewhat lower than that of the United States. Moreover, the real exchange rate and private consumption always increases over the medium-run after an increase in equity prices, though again the permanence of this effect differs markedly across countries. The strength of the reaction of private consumption for most countries suggests that wealth effects constitute an important channel through which asset price shocks affect the trade balance of countries.

\footnotetext{
${ }^{3}$ Moreover, this positive effect of asset prices on the exchange rate is not necessarily inconsistent with the literature that finds a negative correlation between equity returns and exchange rate movements (Hau and Rey, 2006, Andersen et al., 2007) as those correlations are unconditional ones and may stem from other types of shocks.
} 
Table 2: Impulse Response to a 10 percent domestic asset price shock

\section{USA UK Germany France Italy Canada Japan}

\begin{tabular}{lrrrrrrr}
\hline 1 quarter & & & & & & & \\
trade balance & -0.36 & 1.28 & -0.09 & -0.17 & -0.70 & -0.17 & 0.28 \\
REER & 3.12 & 2.72 & -0.66 & 0.62 & 0.95 & 1.62 & 3.43 \\
consumption & 4.88 & 4.37 & 0.80 & 4.34 & 4.57 & 3.57 & 4.06 \\
inflation & 0.75 & 2.48 & 0.71 & 0.81 & 1.01 & 1.23 & 1.69 \\
interest rates & 1.88 & 4.81 & 0.87 & 1.41 & 1.41 & 2.25 & 1.83 \\
equity markets & 10.00 & 10.00 & 10.00 & 10.00 & 10.00 & 10.00 & 10.00 \\
\hline 8 quarters & & & & & & & \\
trade balance & -0.66 & 0.28 & -1.02 & -0.58 & -0.43 & -0.04 & 0.21 \\
REER & 5.11 & 6.11 & 3.10 & 0.47 & 2.70 & 6.79 & 11.26 \\
consumption & 7.09 & 5.19 & 9.31 & 0.75 & 2.94 & 9.59 & 13.13 \\
inflation & 0.43 & -1.25 & 0.24 & 0.29 & 0.67 & 0.06 & 0.38 \\
interest rates & 0.69 & -0.15 & 0.83 & 0.59 & 1.40 & 0.10 & 0.03 \\
equity markets & 6.37 & -0.70 & 0.70 & -2.04 & 5.78 & 12.04 & 11.38 \\
\hline 16 quarters & & & & & & & \\
trade balance & -0.91 & -0.16 & -0.87 & -0.06 & 0.32 & -0.61 & -0.25 \\
REER & 4.64 & 1.99 & 1.47 & -0.16 & 1.38 & 4.83 & 5.39 \\
consumption & 7.29 & -0.10 & 5.38 & -0.31 & 1.01 & 6.74 & 7.99 \\
inflation & -0.03 & -0.40 & 0.07 & 0.12 & 0.12 & 0.07 & 0.30 \\
interest rates & 0.38 & 0.16 & 0.16 & 0.28 & 1.02 & 0.18 & 0.08 \\
equity markets & 0.79 & 2.38 & 2.00 & -0.16 & 1.63 & 10.86 & -0.80 \\
\hline \hline
\end{tabular}

Notes: The table shows the responses of the various variables 1 quarter, 8 quarters and 16 quarters after a positive $10 \%$ shock to relative equity prices, i.e. a 10 percent rise of domestic asset prices relative to those in the rest of the world.

Nominal interest rates and inflation also rise in the short-run, though recall that we imposed this response for the first four quarters in order to identify asset price shocks. However, the magnitude and the persistence of the reaction of interest rates and inflation again differ substantially across countries. We also note and show the impulse responses for countries with somewhat puzzling results. For instance, the trade balance for the UK (Figure 2) improves in response to a positive domestic asset price shock.

Table 2 illustrates the heterogeneity of the point estimates at different time horizons, after 1 quarter, 8 quarters and 16 quarters, respectively. The table shows the marked differences in the impulse responses across countries, with in the magnitude as well as in the dynamics and timing of the transmission of asset price shocks. For instance, Italy's trade balance appears to react relatively quickly to asset price 
shocks, with the impulse response reverting back to zero relatively quickly. By contrast, the opposite is the case for the UK, where the reduction in the trade balance materializes only after several quarters.

Table 2 also nicely illustrates the different channels that are at play in transmitting the asset price shock to the trade balance of countries. Countries that experience a stronger reaction of their trade balance to the asset price shock also exhibit a larger response of their real effective exchange rate as well as private consumption. For instance, for the reaction after 16 quarters, it is in particular the United States but also Germany and Canada that see the strongest response of their trade balance, yet also experience a relatively larger sensitivity of private consumption and of their REER to the asset price shock. Hence, this suggests that both a wealth effect on private consumption as well as a exchange rate channel are at play in explaining the transmission of an asset price shock to a country's trade balance.

Finally, the current financial market turmoil has further increased the focus on the role of monetary policy in addressing asset prices, and in particular asset price bubbles. What do the impulse responses tell us about the potential role of monetary policy as a channel through which asset price shocks may be transmitted to the trade balance of countries? In principle, one would expect that an aggressive tightening of monetary policy in response to a positive asset price shock should dampen the effect of this shock on consumption and thus on net exports through the wealth channel. However, on the other hand, such a tightening may lead to an appreciation of the exchange rate and a worsening of the trade balance. Based on the impulse responses in Figures 1-7, and the summary of these impulse responses shown in Table 2, there seems to be no clear-cut relationship between the response of interest rates, private consumption, inflation and the trade balance across countries. This of course is no more than suggestive, and does not necessarily imply that monetary policy is not relevant for influencing the impact of asset prices on the trade balance. However, for instance for the United States these findings suggest that the reaction of US short-term interest rates to asset price shocks is not systematically lower than that of other industrialized countries.

\subsection{Robustness and extensions}

How robust are these findings across alternative specifications, country samples and time periods? We conduct several robustness tests on the benchmark model. ${ }^{4}$

One important issue is how dependent our empirical findings are on the identification, i.e. the sign restrictions we impose. While these sign restrictions seems sensible, it is nevertheless useful to see how the results change when using alternative identification methods. We do so by estimating our six-variable VAR using a Choleski decomposition. More precisely, we estimate the VAR using each pos-

\footnotetext{
${ }^{4}$ We show here only the corresponding results for the United States, though the conclusions on the robustness checks are qualitatively similar for other countries.
} 
sible ordering of the six endogenous variables, and then check the distribution of the resulting impulse response functions. Figure 8 shows the impulse responses of the trade balance to a positive asset price shock for the case of the United States, the UK, Germany and France. The top of the shaded area represents to maximum response coefficient among the different Choleski decompositions, while the lower end shows the minimum response at any time horizon. Overall, the findings suggest that the direction of the trade balance response to an asset price shock is mostly the same when taking the Choleski decomposition as when using sign restrictions. However, the range of possible impulse responses is in several cases very large, underlining that the shape of the impulse responses is strongly dependent on the zero restrictions imposed on the variance-covariance matrix.

As a next step, we use alternative variables and variable definitions to check how sensitive the findings are to such changes. First, we use the current account instead of the trade balance, taking into account the fact that the dynamics of both can be considerably different for some countries. Figure 9 shows the impulse responses of this specification for the United States and confirms the basic thrust of the benchmark results as the current account declines considerably after a positive asset price shock. In fact, the reaction of the current account is somewhat stronger, as one would indeed expect, likely due to the decline not only of the trade balance but also of the income part of the current account.

Second, we use relative equity market capitalization, ${ }^{5}$ rather than equity prices, to define asset price shocks. Figure 10 shows that the pattern of the impulse responses is unchanged for the United States (as well as for other industrialized countries, which are not shown for brevity reasons).

As a third robustness check, we shorten the time sample to 1990-2007 in order to allow for the possibility that asset price shocks may have become more important over time as countries have become more integrated financially and through trade. Figure 11 shows that the initial reaction of the trade balance is slightly larger and the response of private consumption significantly larger for the United States, lending some support to this conjecture.

In summary, asset price shocks appear to have a significant effect on the trade balance of countries, partly through wealth effects on domestic consumption and partly through an exchange rate channel that leads a real appreciation of the domestic currency. Moreover, there are substantial cross-country differences in the effect of asset price shocks, with the trade balance of the United States in particular exhibiting one of the largest reactions to asset price shocks.

\footnotetext{
${ }^{5}$ Relative equity market capitalization is measured as the difference in the log domestic market capitalization and the log rest-of-the-world market capitalization, both measured in US dollars. Using market exchange rates or PPP exchange rates does not change the findings in a meaningful way. More recisely, While the magnitude of the impulse responses may change depending on the specification, the direction and dynamics is very similar across specifications.
} 


\section{Conclusions}

The paper has analysed the effect of asset price shocks on the current account. Its focus has been on the experience of the cross-section of G7 industrialized countries. We have employed a Bayesian VAR with sign restrictions in order not only to motivate the identifying restrictions for asset price shocks, but also to ensure that we can distinguish this type of shock from other shocks, such as to productivity, monetary policy and government spending. The empirical evidence suggests that asset price shocks indeed exert a significant effect on the trade balance of countries, partly through a wealth channel of private consumption and partly via an exchange rate channel.

One of the central findings of the paper is the substantial cross-country heterogeneity that we detect in the sensitivity of the trade balance to asset price shocks. In particular the US trade balance seems to be among the most sensitive to relative asset price shocks, falling by 0.91 percentage points in response to a 10 percent increase in US equity prices relative to the rest of the world. By contrast, other countries' trade balances appear to be less responsive to asset price shocks.

Many open questions remain and there are various future avenues for better understanding the importance of asset price shocks, both domestically and globally. In particular against the background of the financial market turmoil of 2007-08, the role of monetary policy for asset prices remains unclear. Similarly, the focus of the present paper has been only on equity markets. Extending the analysis to housing markets seems particularly relevant in the current financial market context. Another important avenue is to extend the analysis to emerging markets, which are rapidly becoming ever more important players in the global economy and international financial markets. We leave these avenues for future research. 


\section{References}

[1] Andersen, T., Bollerslev, T., Diebold, F. and C. Vega, 2007. Real-Time Price Discovery in Stock, Bond and Foreign Exchange Markets, Journal of International Economics 73, 251-277.

[2] Bernanke, B., 2005. The Global Saving Glut and the U.S. Current Account Deficit. Sandridge Lecture, Virginia Association of Economics, 10 March 2005.

[3] Bertaut, C., 2002. Equity Prices, Household Wealth, and Consumption Growth in Foreign Industrial Countries: Wealth Effects in the 1990s, Federal Reserve Board International Finance Discussion Paper No. 724.

[4] Beaudry, P. and F. Portier, 2006. News, Stock Prices and Economic Fluctuations, American Economic Review 96(4), September, 2006.

[5] Beaudry, P. and F. Portier, 2007. When can Changes in Expectations cause Business Cycle Fluctuations, Journal of Economic Theory 135(1), 2007.

[6] Blanchard, O., F. Giavazzi and F. Sa, 2005. The U.S. Current Account and the Dollar, Brookings Papers on Economic Activity 1, 1-65.

[7] Bussiere, M., M. Fratzscher and G. Müller, 2005. Productivity Shocks, Budget Deficits and the Current Account. ECB Working Paper No. 509, August 2005.

[8] Caballero, R., E. Farhi and P.-O. Gourinchas, 2006. An Equilibrium Model of 'Global Imbalances' and Low Interest Rates. MIT and University of California, Berkeley, mimeo.

[9] Canova, F. and G. de Niccolo, 2002. Monetary Disturbances Matter for Business Cycle Fluctuations in G-7, Journal of Monetary Economics, 49(6), 1131-1159.

[10] Case, K.E., J.M. Quigley and R.J. Shiller, 2005. Comparing Wealth Effects: The Stock Market versus the Housing Market, B.E. Advances in Macroeconomics 5(1), Article 1.

[11] Chinn, M. and H. Ito, 2007. Current Account Balances, Financial Development and Institutions: Assaying the World 'Saving Glut', Journal of International Money and Finance.

[12] Clarida, Richard and Daniel Waldman, 2007. Is Bad News About Inflation Good News for the Exchange Rate? NBER Working Paper No. 13010.

[13] Corsetti, G., L. Dedola and S. Leduc, 2006. Productivity, External Balance and Exchange Rates: Evidence on the Transmission Mechanism Among G7 Countries, NBER Working Paper 12483. 
[14] Ehrmann, M., M. Fratzscher and R. Rigobon, 2005. Stocks, bonds, money markets and exchange rates: Measuring international financial transmission, NBER Working Paper 11166.

[15] Engel, C., 1996. The Forward Discount Anomaly and the Risk Premium: A Survey of Recent Evidence. Journal of Empirical Finance 3, 123-192.

[16] Engel, C. and J. Rogers, 2006. The U.S. Current Account Deficit and the Expected Share of World Output, Journal of Monetary Economics 53(5), 10631093.

[17] Engel, C. and K. West, 2005. Taylor Rules and the Deutschmark-Dollar Real Exchange Rate, Journal of Money, Credit and Banking 38(5), 1175-94.

[18] Fogli, A. and F. Perri, 2006. The Great Moderation and the US External Imbalance, NBER Working Paper No. 12708.

[19] Fratzscher, M., L. Juvenal and L. Sarno, 2007. Asset prices, exchange rates and the current account, ECB Working Paper No. 790.

[20] Fratzscher, M. and R. Straub, 2008. The role of asset price shocks, financial integration and home bias for understanding global current account dynamics, mimeo April 2008.

[21] Gourinchas, P.-O. and H. Rey, 2007. International Financial Adjustment, Journal of Political Economy, 115 (4): 665-703.

[22] Gruber, J. and S. Kamin, 2007. Explaining the Global Pattern of Current Account Imbalances, Journal of International Money and Finance.

[23] Hau, H. and H. Rey, 2006. Exchange Rates, Equity Prices and Capital Flows," Review of Financial Studies 19 (1), 273-317.

[24] Ju, J. and S.-J. Wei, 2006. A Solution to Two Paradoxes of International Capital Flows, mimeo, June 2006.

[25] Kraay, A. and J. Ventura, 2005. The Dot-Com Bubble the Bush Deficits, and the U.S. Current Account. NBER Working Paper No. 11543.

[26] Krugman, P., 2007. Will There Be a Dollar Crisis? Economic Policy, Vol. $22(51), 435-67$.

[27] Lane, P. and G.M. Milesi-Ferretti, 2005, A Global Perspective on External Positions. In G7 Current Account Imbalances: Sustainability and Adjustment, edited by Clarida, R.H. Chicago: Chicago University Press. 
[28] Lettau and Ludvigson, 2004. Understanding Trend and Cycle in Asset Values: Reevaluating the Wealth Effect on Consumption, American Economic Review $94,276-299$.

[29] Matsumoto, A., P. Cova, M. Pisani, A. Rebucci, 2008. News shocks, exchange rates and equity prices, mimeo, IMF and Banca d'Italia.

[30] Obstfeld, M. and K. Rogoff, 2005. Global Current Account Imbalances and Exchange Rate Adjustments, Brookings Papers on Economic Activity 1, 67146.

[31] Palumbo, Rudd, and Whelan, 2006. On the Relationships between Real Consumption, Income, andWealth, Journal of Business and Economic Statistics $24,1-11$

[32] Peersman, G., 2003. What Caused the Early Millennium Slowdown? Evidence Based on Vector Autoregressions, CEPR Discussion Paper, 4087.

[33] Peersman, G., and R. Straub, 2006. Technology Shocks and Robust Sign Restrictions in a Euro Area SVAR, forthcoming International Economic Review.

[34] Pesaran, M.H., Schuermann, T. and Weiner, S.M. 2004. Modelling Regional Interdependencies Using a Global Error-Correcting Macroeconometric Model. Journal of Business \&5 Economic Statistics, 22, 129-162.

[35] Uhlig, H., 2005. What are the Effects of Monetary Policy on Output? Results from an Agnostic Identification Procedure. Journal of Monetary Economics 52, 381-419.

[36] Ventura, J., 2001. A Portfolio View of the US Current Account Deficit, Brookings Papers on Economic Activity 1, 241-253. 
DATA APPENDIX

Table 3: Country sample

\begin{tabular}{ccc}
\hline Benchmark sample & \multicolumn{2}{c}{ Extended sample with EMEs } \\
\hline USA & Countries of benchmark \\
UK & Argentina & Mexico \\
Germany & Austria & New Zealand \\
France & Brazil & Peru \\
Italy & Chile & Philippines \\
Canada & China & Poland \\
Japan & Colombia & Portugal \\
Australia & Czech Republic & Romania \\
Belgium & Greece & Russia \\
Denmark & Hong Kong & South Africa \\
Finland & Hungary & Singapore \\
Netherlands & India & Slovakia \\
Norway & Indonesia & South Korea \\
Spain & Ireland & Thailand \\
Sweden & Malaysia & Turkey \\
Switzerland & & \\
\hline
\end{tabular}



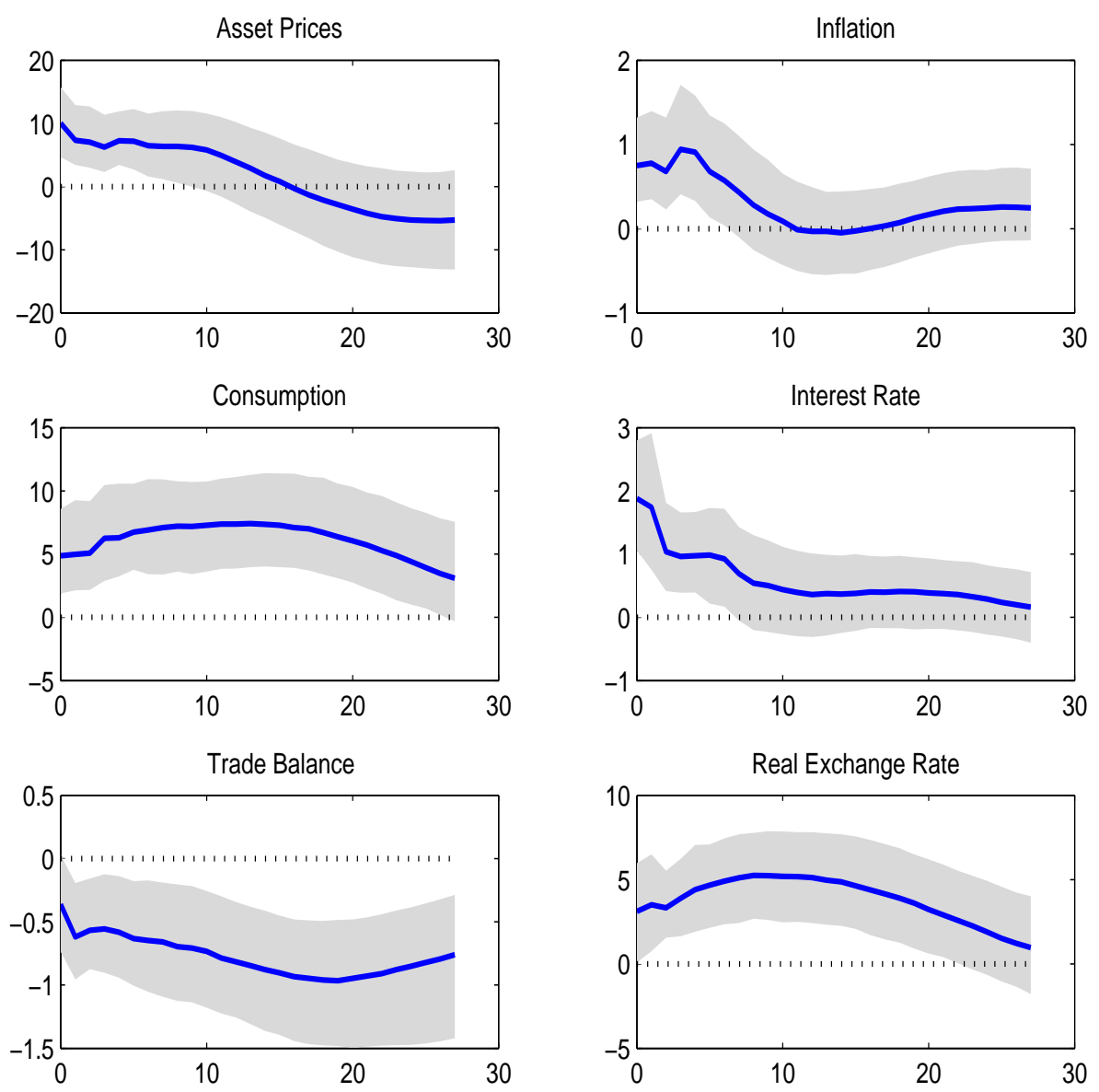

Figure 1: United States- Impulse Response following an Asset Price Shock 

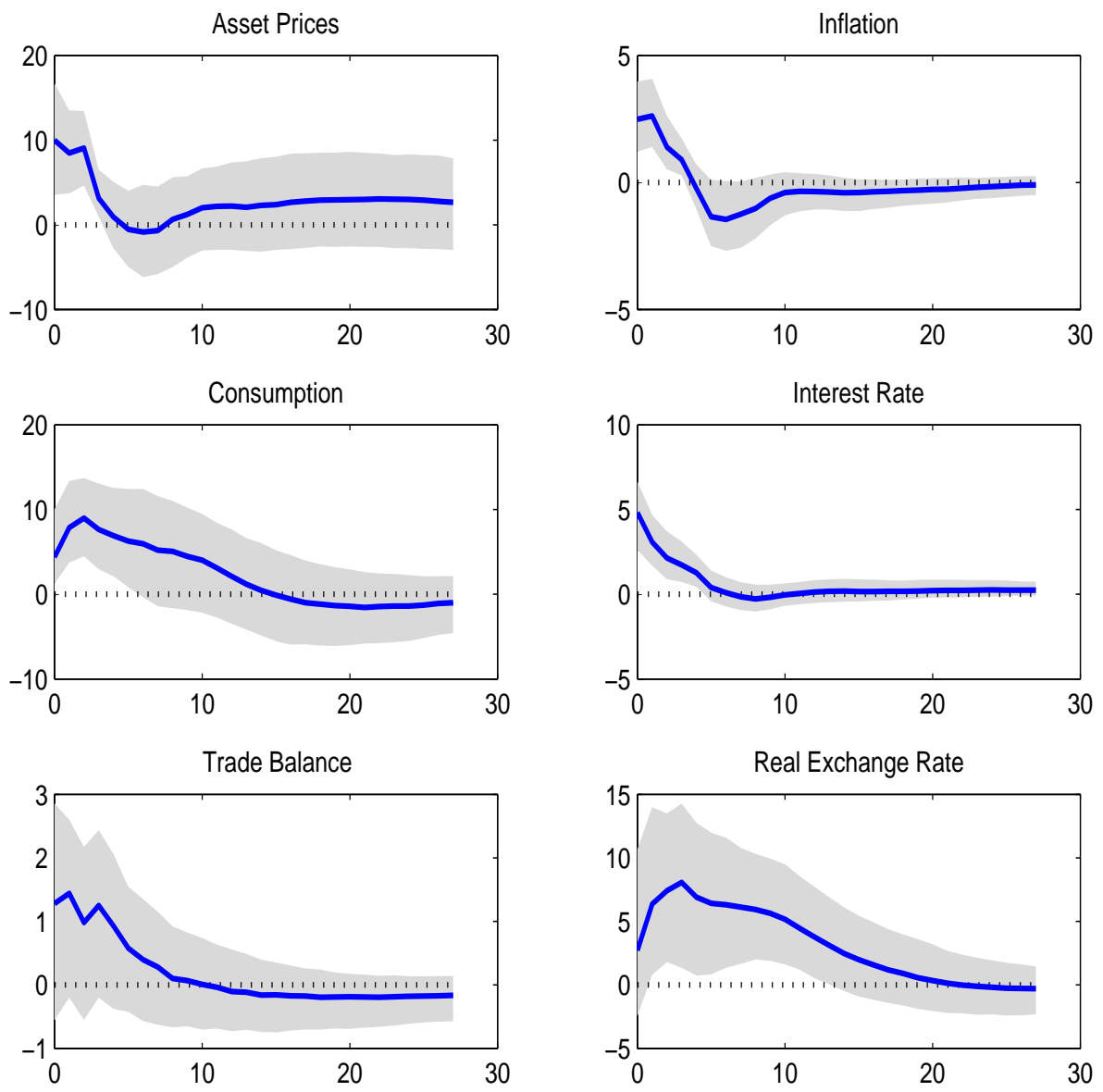

Figure 2: United Kingdom- Impulse Response following an Asset Price Shock 

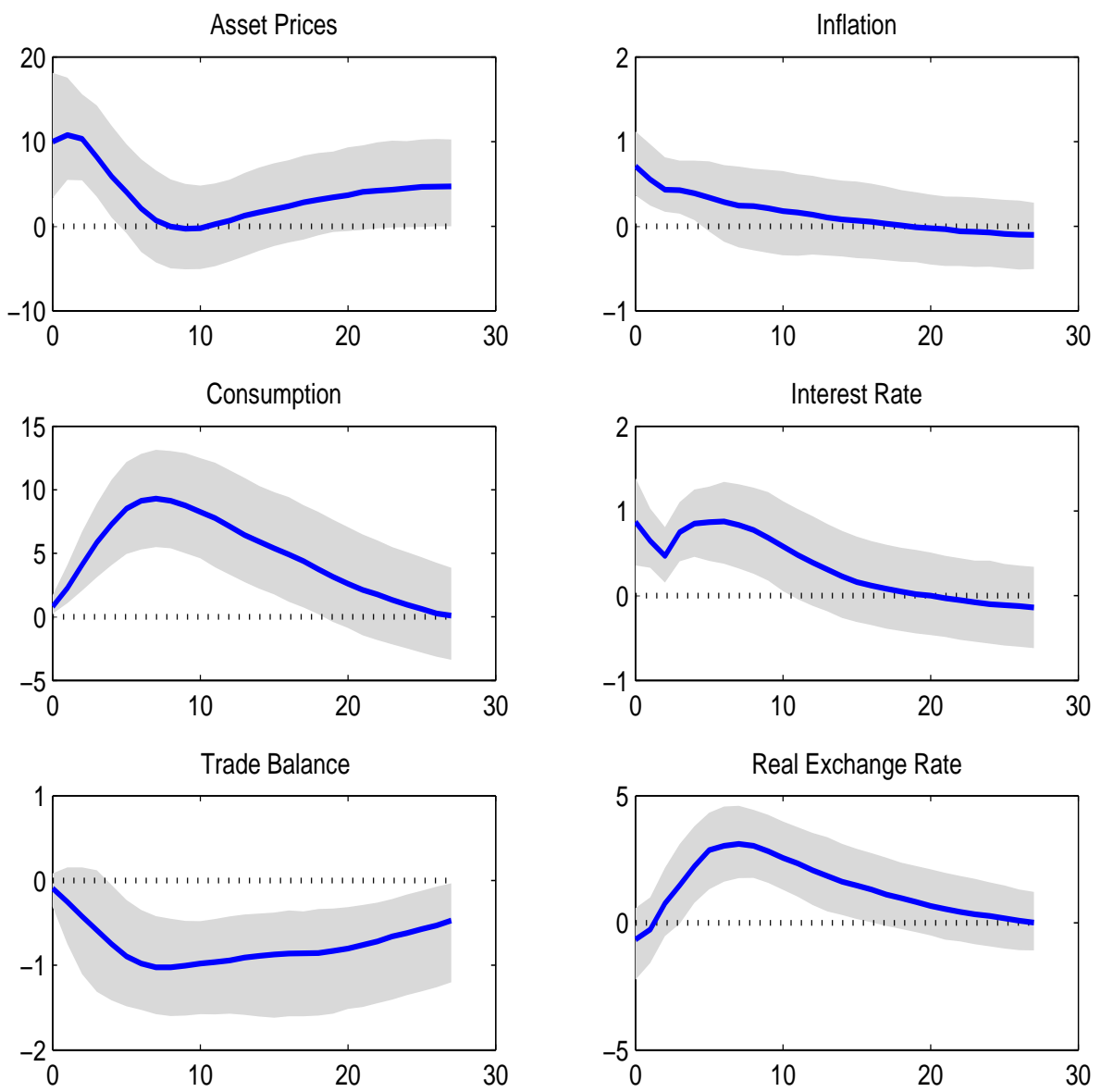

Figure 3: Germany- Impulse Response following an Asset Price Shock 

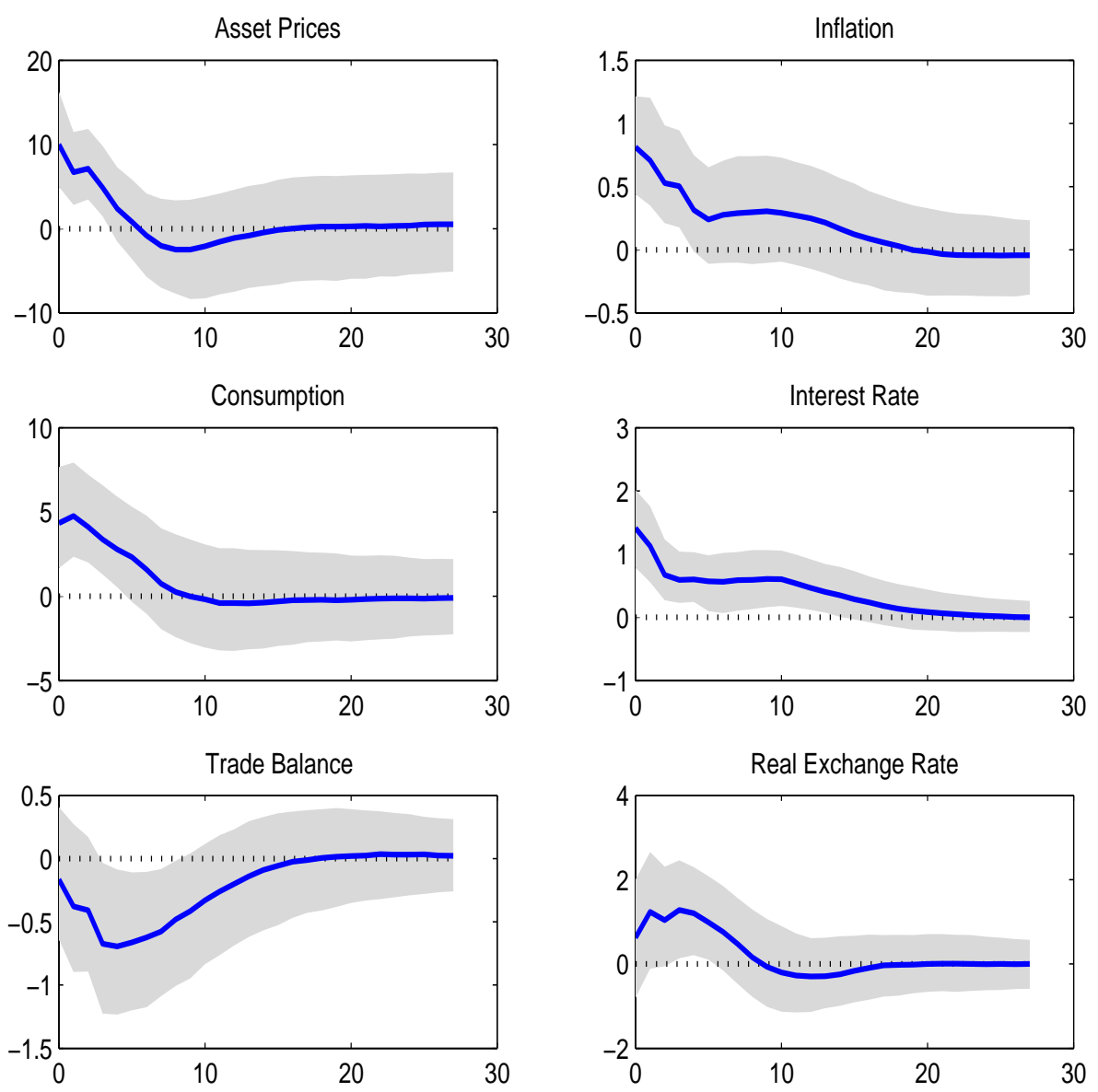

Figure 4: France- Impulse Response following an Asset Price Shock 

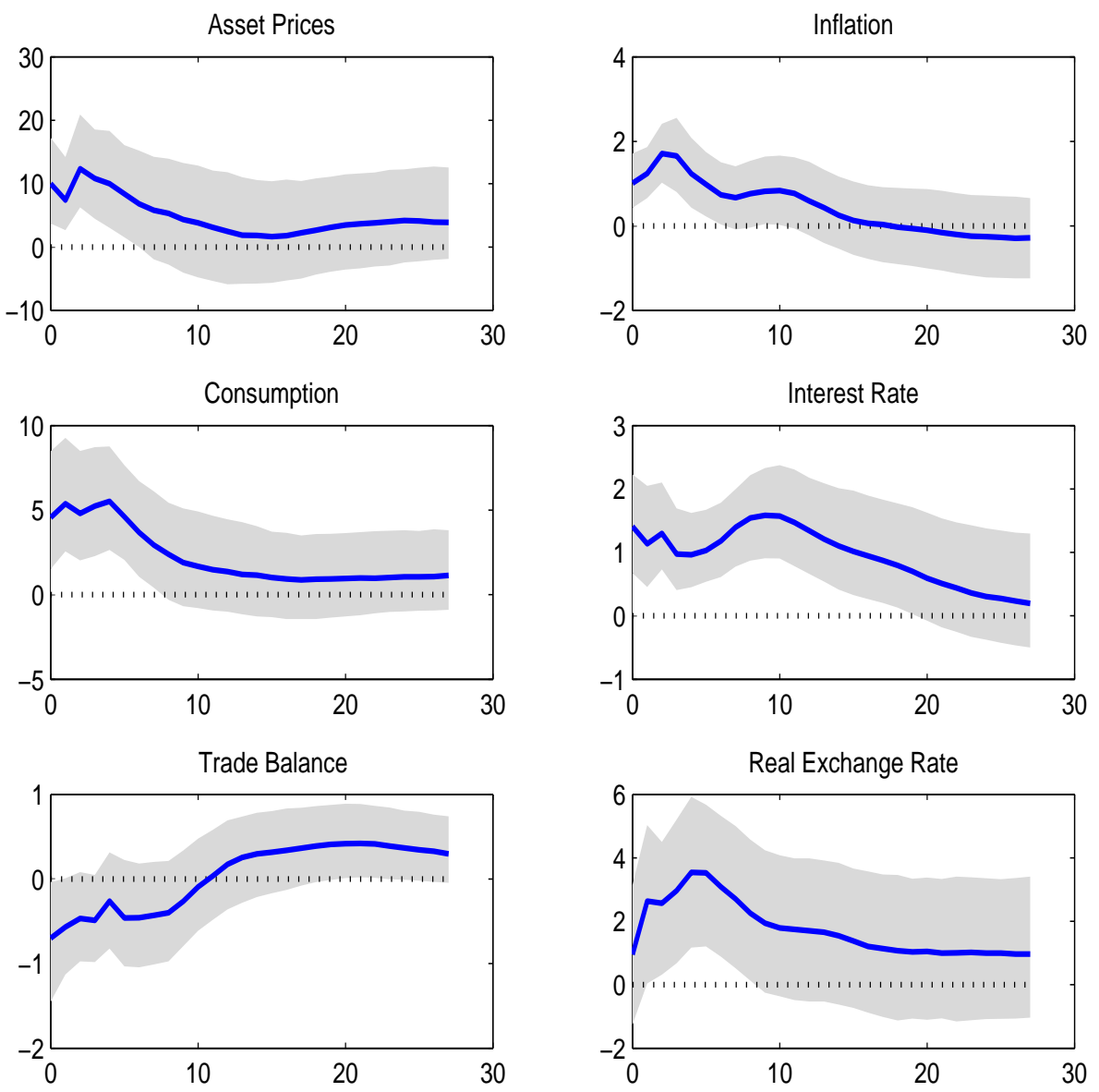

Figure 5: Italy- Impulse Response following an Asset Price Shock 

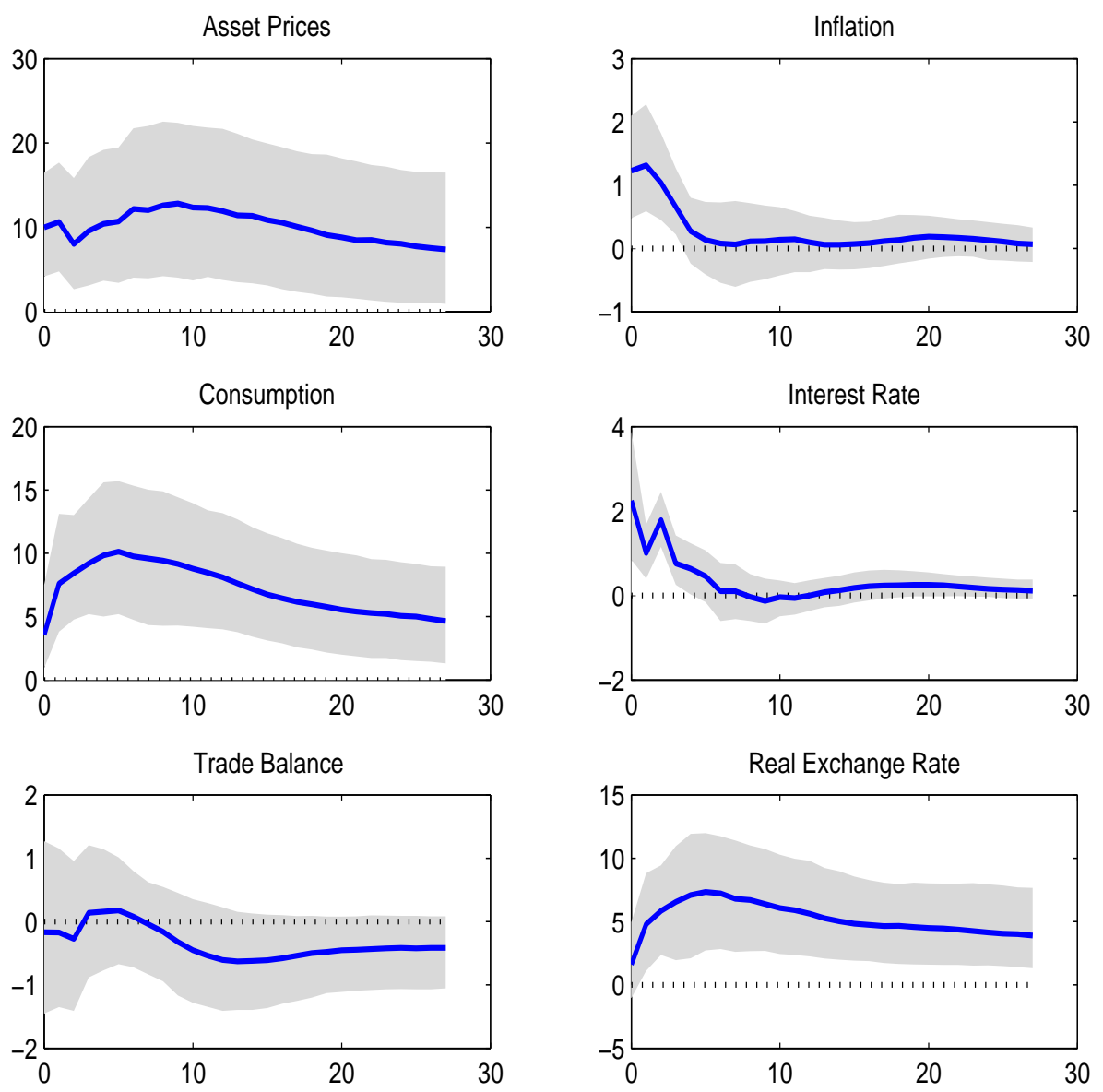

Figure 6: Canada- Impulse Response following an Asset Price Shock 

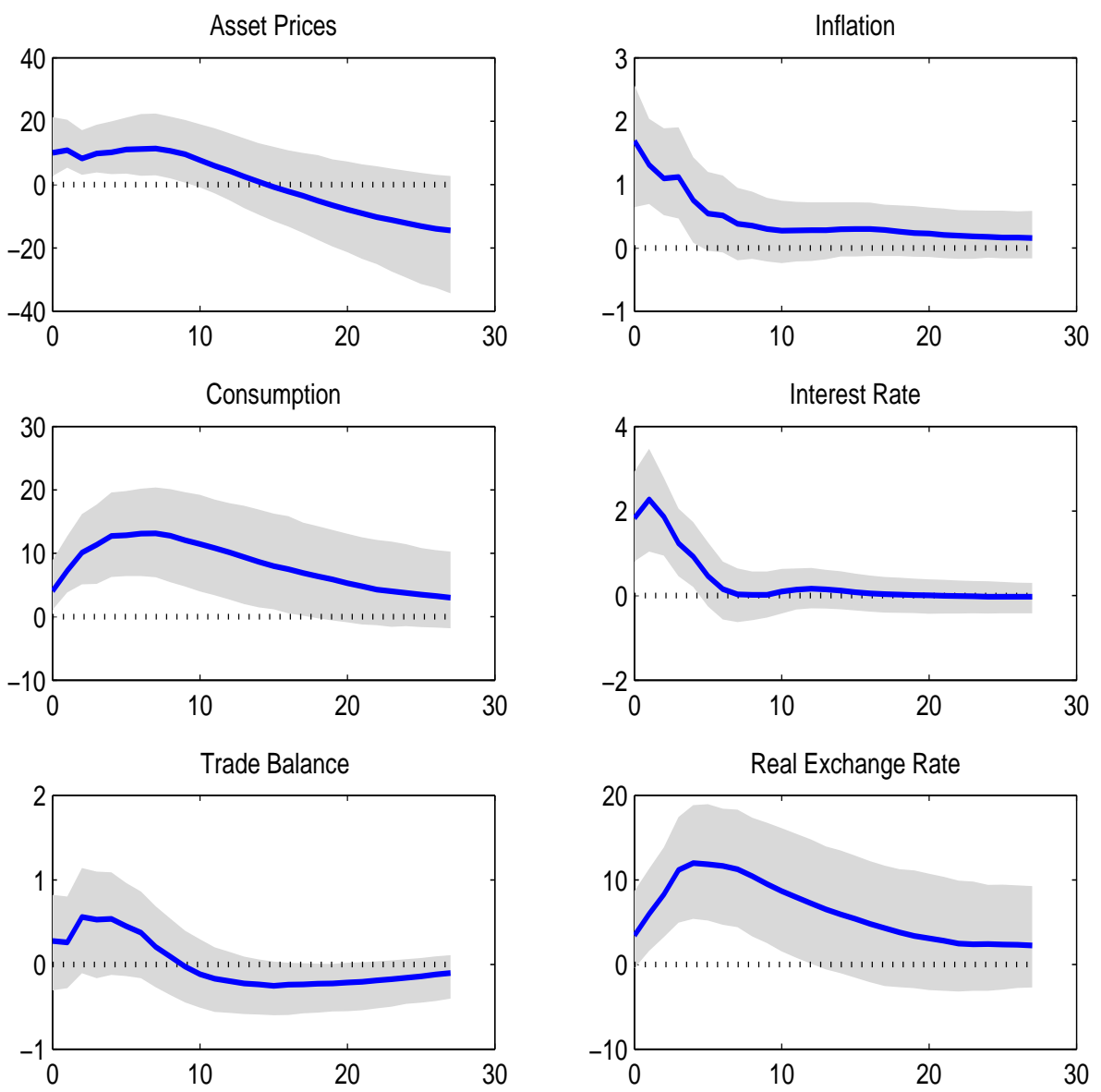

Figure 7: Japan- Impulse Response following an Asset Price Shock 

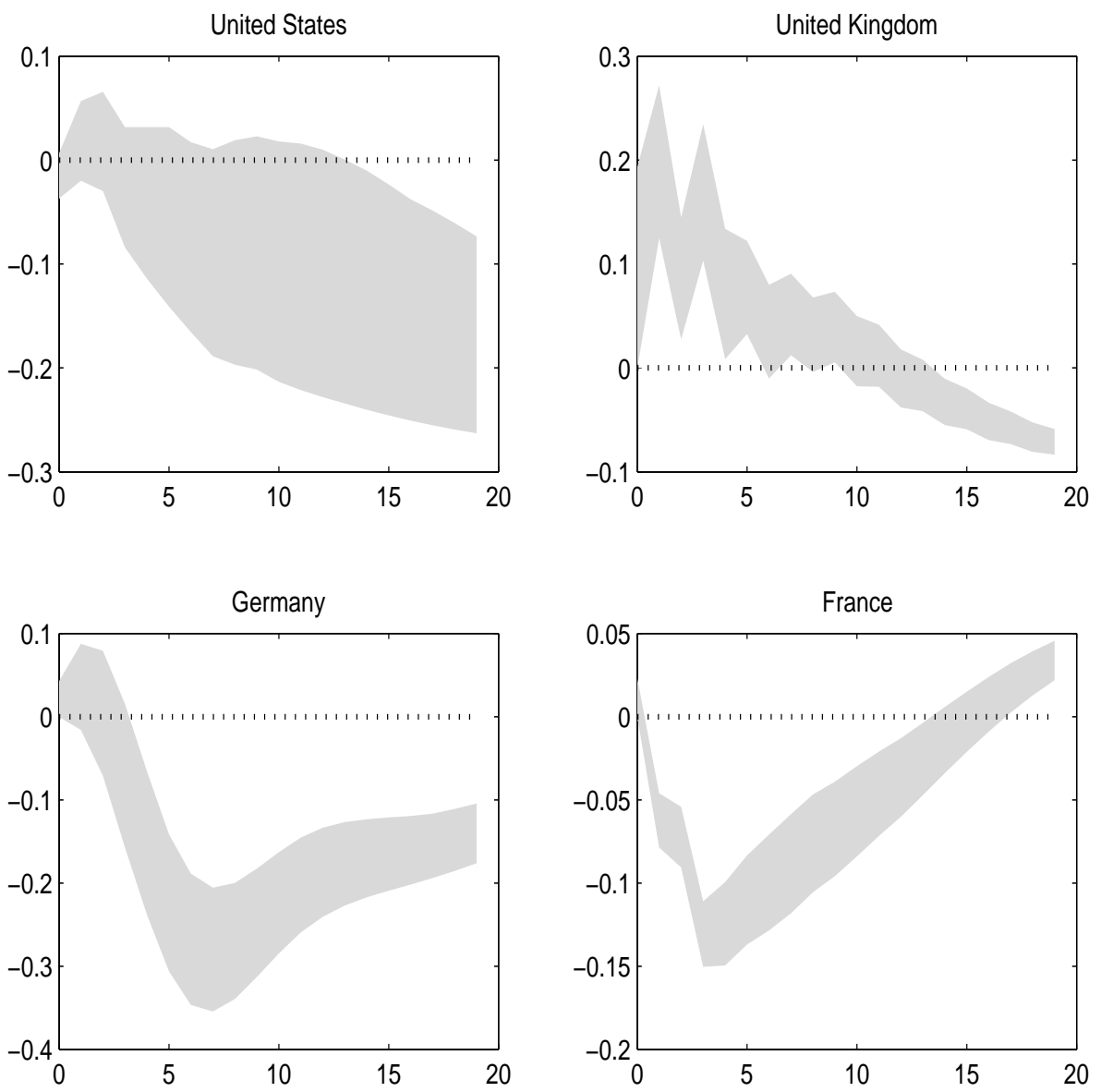

Figure 8: Impulse Response following Choleski Decomposition 

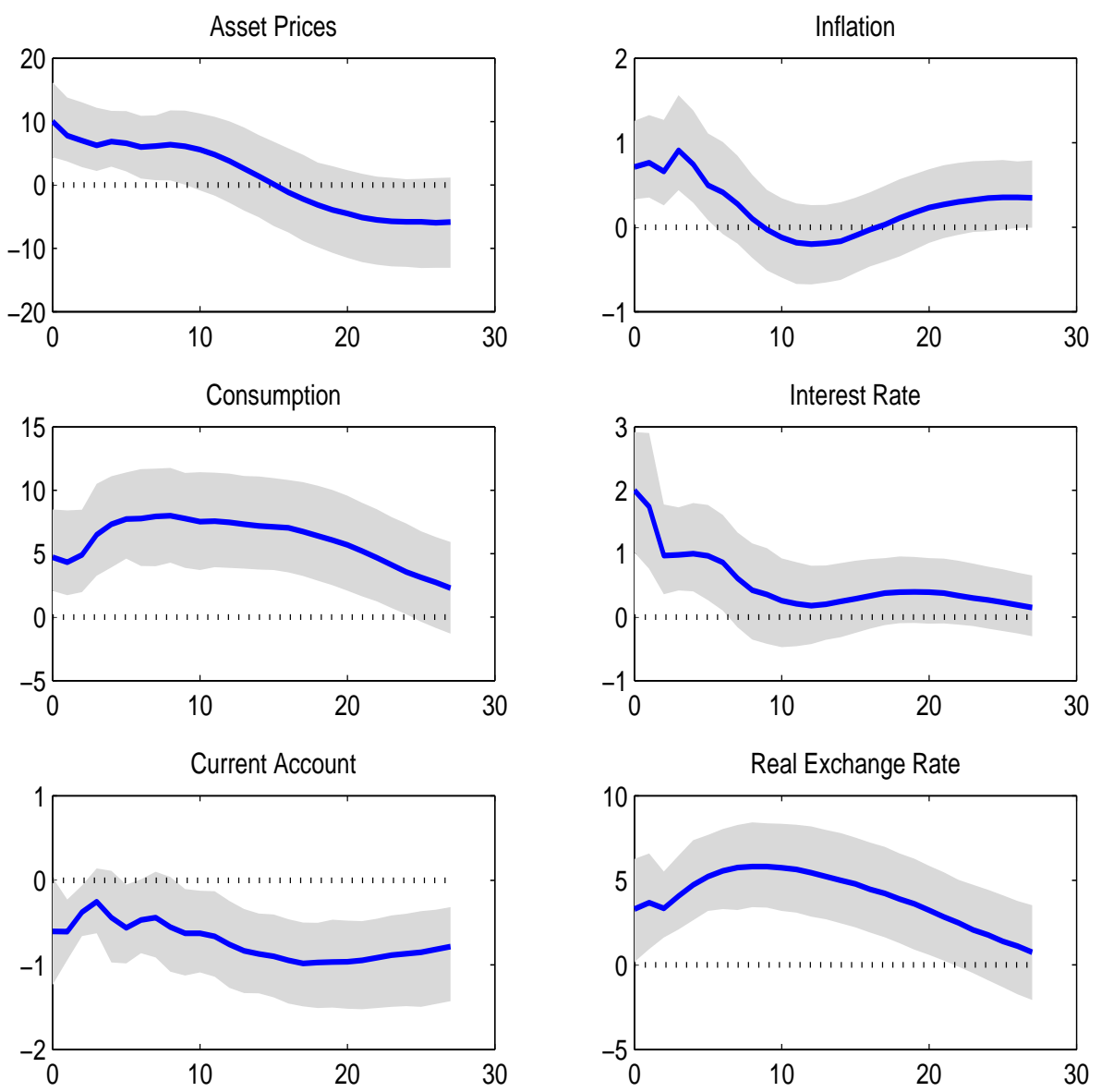

Figure 9: United States- Impulse Response following an Asset Price Shock with Current Account 

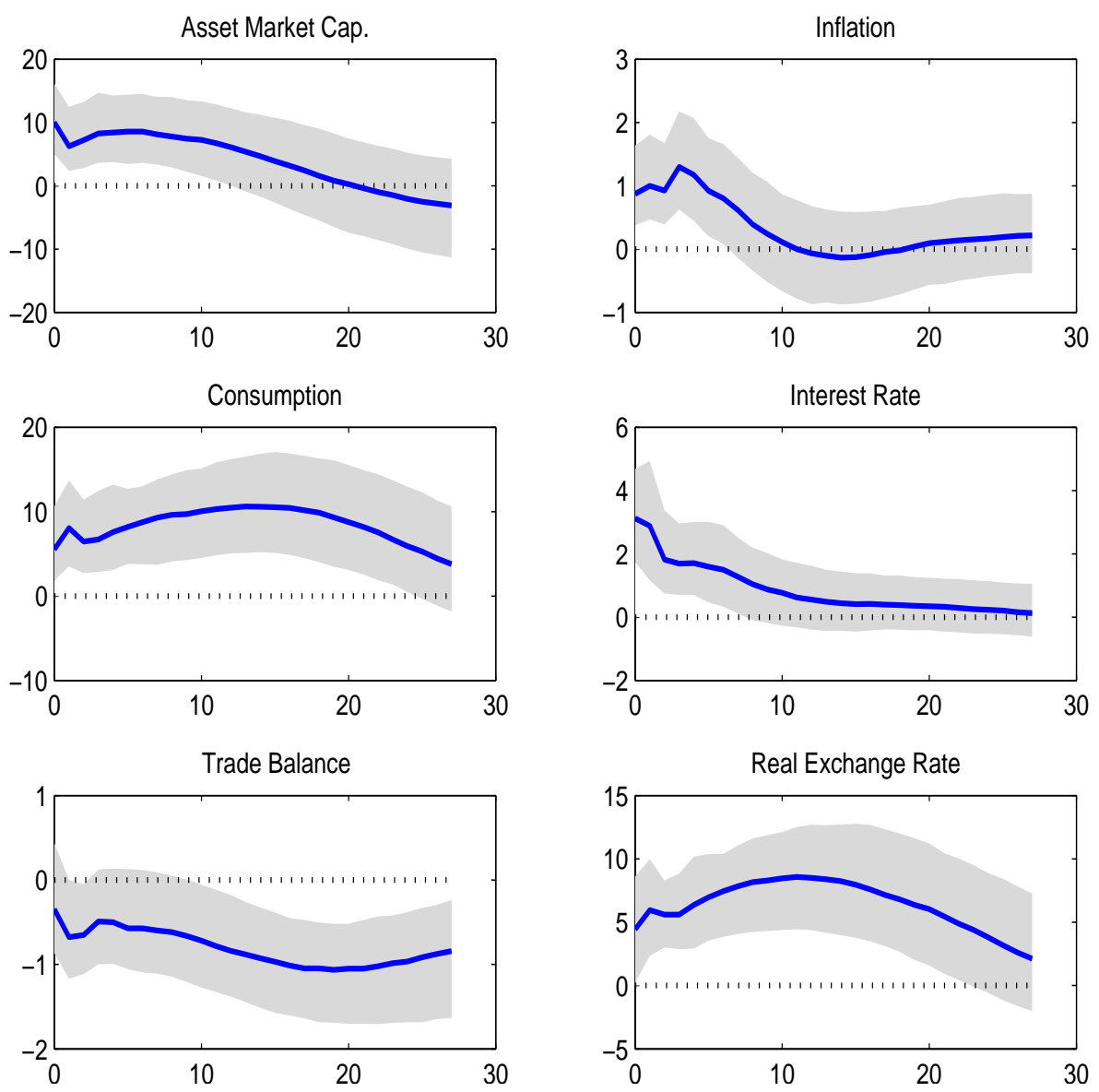

Figure 10: United States- Impulse Response following an Asset Price Shock with Equity Market Capitalization 

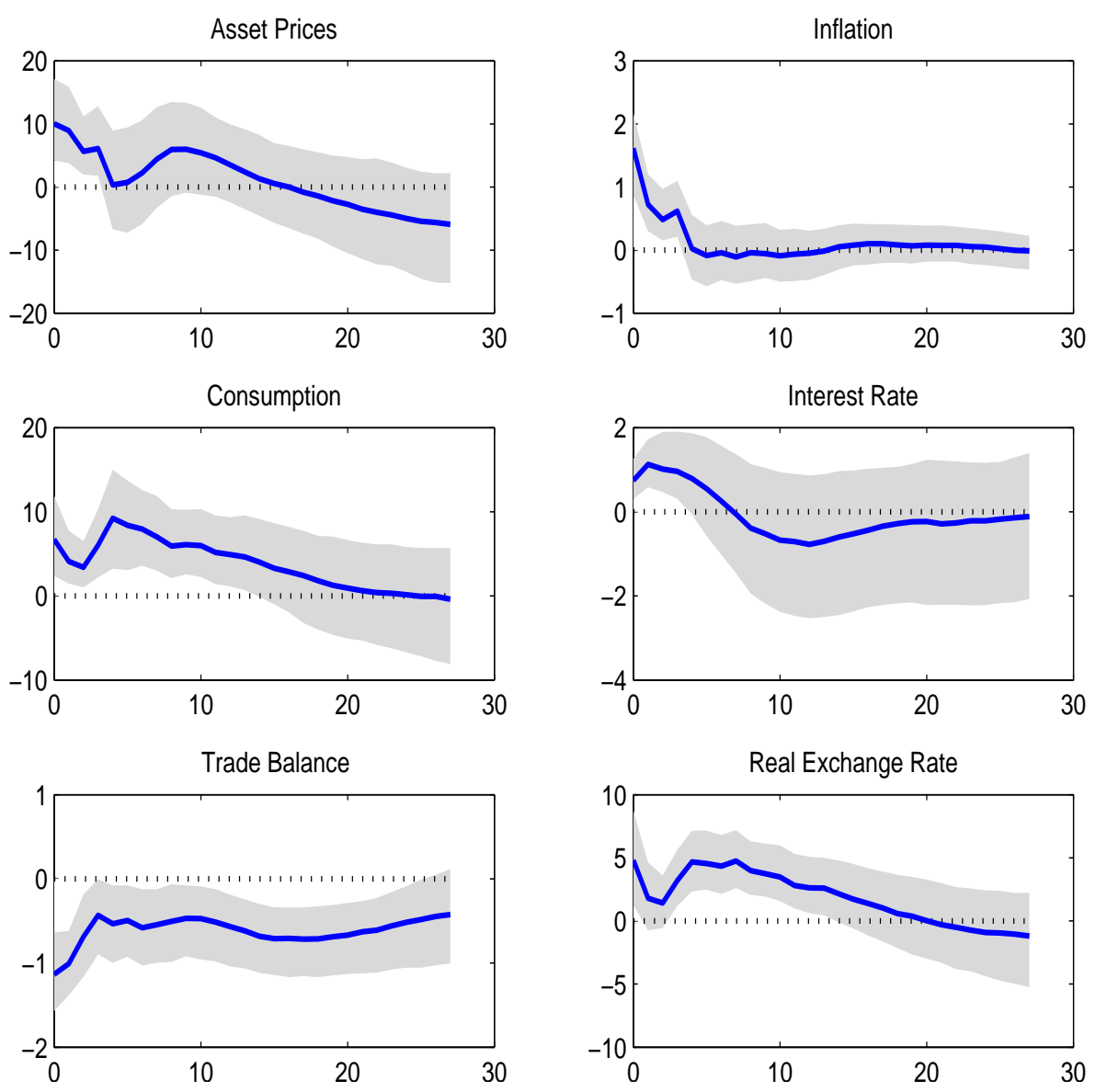

Figure 11: United States- Impulse Response following an Asset Price Shock with time sample 1990-2007 


\section{European Central Bank Working Paper Series}

For a complete list of Working Papers published by the ECB, please visit the ECB's website (http://www.ecb.europa.eu).

956 "The political economy under monetary union: has the euro made a difference?" by M. Fratzscher and L. Stracca, November 2008.

957 "Modeling autoregressive conditional skewness and kurtosis with multi-quantile CAViaR" by H. White, T.-H. Kim, and S. Manganelli, November 2008.

958 "Oil exporters: in search of an external anchor" by M. M. Habib and J. Stráský, November 2008.

959 “What drives U.S. current account fluctuations?" by A. Barnett and R. Straub, November 2008.

960 "On implications of micro price data for macro models" by B. Maćkowiak and F. Smets, November 2008.

961 "Budgetary and external imbalances relationship: a panel data diagnostic" by A. Afonso and C. Rault, November 2008.

962 "Optimal monetary policy and the transmission of oil-supply shocks to the euro area under rational expectations" by S. Adjemian and M. Darracq Pariès, November 2008.

963 "Public and private sector wages: co-movement and causality" by A. Lamo, J. J. Pérez and L. Schuknecht, November 2008.

964 "Do firms provide wage insurance against shocks? Evidence from Hungary" by G. Kátay, November 2008.

965 "IMF lending and geopolitics" by J. Reynaud and J. Vauday, November 2008.

966 “Large Bayesian VARs” by M. Bańbura, D. Giannone and L. Reichlin, November 2008.

967 "Central bank misperceptions and the role of money in interest rate rules" by V. Wieland and G. W. Beck, November 2008.

968 "A value at risk analysis of credit default swaps" by B. Raunig and M. Scheicher, November 2008.

969 "Comparing and evaluating Bayesian predictive distributions of asset returns" by J. Geweke and G. Amisano, November 2008.

970 "Responses to monetary policy shocks in the east and the west of Europe: a comparison" by M. Jarociński, November 2008.

971 "Interactions between private and public sector wages" by A. Afonso and P. Gomes, November 2008.

972 "Monetary policy and housing prices in an estimated DSGE for the US and the euro area" by

M. Darracq Pariès and A. Notarpietro, November 2008.

973 "Do China and oil exporters influence major currency configurations?" by M. Fratzscher and A. Mehl, December 2008.

974 "Institutional features of wage bargaining in 23 European countries, the US and Japan" by P. Du Caju, E. Gautier, D. Momferatou and M. Ward-Warmedinger, December 2008.

975 "Early estimates of euro area real GDP growth: a bottom up approach from the production side" by E. Hahn and F. Skudelny, December 2008. 
976 "The term structure of interest rates across frequencies" by K. Assenmacher-Wesche and S. Gerlach, December 2008.

977 "Predictions of short-term rates and the expectations hypothesis of the term structure of interest rates" by M. Guidolin and D. L. Thornton, December 2008.

978 "Measuring monetary policy expectations from financial market instruments" by M. Joyce, J. Relleen and S. Sorensen, December 2008.

979 "Futures contract rates as monetary policy forecasts" by G. Ferrero and A. Nobili, December 2008.

980 "Extracting market expectations from yield curves augmented by money market interest rates: the case of Japan" by T. Nagano and N. Baba, December 2008.

98I "Why the effective price for money exceeds the policy rate in the ECB tenders?" by T. Välimäki, December 2008.

982 "Modelling short-term interest rate spreads in the euro money market" by N. Cassola and C. Morana, December 2008.

983 "What explains the spread between the euro overnight rate and the ECB's policy rate?" by T. Linzert and S. Schmidt, December 2008.

984 “The daily and policy-relevant liquidity effects” by D. L. Thornton, December 2008.

985 "Portuguese banks in the euro area market for daily funds" by L. Farinha and V. Gaspar, December 2008.

986 "The topology of the federal funds market" by M. L. Bech and E. Atalay, December 2008.

987 "Probability of informed trading on the euro overnight market rate: an update" by J. Idier and S. Nardelli, December 2008.

988 "The interday and intraday patterns of the overnight market: evidence from an electronic platform" by R. Beaupain and A. Durré, December 2008.

989 "Modelling loans to non-financial corporations in the euro area” by C. Kok Sørensen, D. Marqués Ibáñez and C. Rossi, January 2009.

990 “Fiscal policy, housing and stock prices” by A. Afonso and R. M. Sousa, January 2009.

991 "The macroeconomic effects of fiscal policy” by A. Afonso and R. M. Sousa, January 2009.

992 "FDI and productivity convergence in central and eastern Europe: an industry-level investigation" by M. Bijsterbosch and M. Kolasa, January 2009.

993 "Has emerging Asia decoupled? An analysis of production and trade linkages using the Asian international input-output table" by G. Pula and T. A. Peltonen, January 2009.

994 "Fiscal sustainability and policy implications for the euro area" by F. Balassone, J. Cunha, G. Langenus, B. Manzke, J. Pavot, D. Prammer and P. Tommasino, January 2009.

995 “Current account benchmarks for central and eastern Europe: a desperate search?” by M. Ca' Zorzi, A. Chudik and A. Dieppe, January 2009.

996 “What drives euro area break-even inflation rates?” by M. Ciccarelli and J. A. García, January 2009. 
997 "Financing obstacles and growth: an analysis for euro area non-financial corporations" by C. Coluzzi, A. Ferrando and C. Martinez-Carrascal, January 2009.

998 “Infinite-dimensional VARs and factor models" by A. Chudik and M. H. Pesaran, January 2009.

999 “Risk-adjusted forecasts of oil prices” by P. Pagano and M. Pisani, January 2009.

1000 "Wealth effects in emerging market economies" by T. A. Peltonen, R. M. Sousa and I. S. Vansteenkiste, January 2009.

I00I "Identifying the elasticity of substitution with biased technical change" by M. A. León-Ledesma, P. McAdam and A. Willman, January 2009.

1002 "Assessing portfolio credit risk changes in a sample of EU large and complex banking groups in reaction to macroeconomic shocks” by O. Castrén, T. Fitzpatrick and M. Sydow, February 2009.

1003 "Real wages over the business cycle: OECD evidence from the time and frequency domains" by J. Messina, C. Strozzi and J. Turunen, February 2009.

1004 “Characterising the inflation targeting regime in South Korea” by M. Sánchez, February 2009.

1005 "Labor market institutions and macroeconomic volatility in a panel of OECD countries" by F. Rumler and J. Scharler, February 2009.

1006 "Understanding sectoral differences in downward real wage rigidity: workforce composition, institutions, technology and competition” by P. Du Caju, C. Fuss and L. Wintr, February 2009.

1007 "Sequential bargaining in a new-Keynesian model with frictional unemployment and staggered wage negotiation" by G. de Walque, O. Pierrard, H. Sneessens and R. Wouters, February 2009.

1008 “Liquidity (risk) concepts: definitions and interactions” by K. Nikolaou, February 2009.

1009 “Optimal sticky prices under rational inattention” by B. Maćkowiak and M. Wiederholt, February 2009.

1010 "Business cycles in the euro area” by D. Giannone, M. Lenza and L. Reichlin, February 2009.

I0II "The global dimension of inflation - evidence from factor-augmented Phillips curves" by S. Eickmeier and K. Moll, February 2009.

1012 "Petrodollars and imports of oil exporting countries" by R. Beck and A. Kamps, February 2009.

1013 "Structural breaks, cointegration and the Fisher effect" by A. Beyer, A. A. Haug and W. G. Dewald, February 2009.

1014 “Asset prices and current account fluctuations in G7 economies” by M. Fratzscher and R. Straub, February 2009. 
